\title{
Effects of Transfromations on Financial Performance of Microfinance NGOs in Kenya
}

\author{
Crispin J. Mbogo \\ Accounting and Finance Department \\ St. Augustine University of Tanzania \\ Mwanza, Tanzania \\ Dr. Kirori N. Gabriel \\ School of Business \\ The Catholic University of Eastern Africa \\ Kenya \\ Prof. Tadeo A. Satta \\ Institute of Finance Management \\ Dar es Salaam \\ Tanzania
}

\begin{abstract}
This study examines effects of transformation on financial performance of microfinance NGOs in Kenya. More specifically; the study seeks to empirically analyze how the selected indicators of transformation affect financial performance of microfinance NGOs in Kenya. The study adopts a quantitative research approach based on unbalanced panel data for 19 years extending from the year 1997 to 2015 acquired from Microfinance Information Exchange (Mix) Market databank on six surveyed transformed microfinance NGOs in Kenya. The study employs panel data regression models. Results indicate that debt to equity ratio and debt to asset ratio are strong drivers of financial performance in the transformed microfinance NGOs in Kenya. Institutional size has revealed significant effects on all selected measures of financial performance. Institutional age showed insignificant effects on return on asset and return on equity but revealed a significant effect on operational selfsufficiency.
\end{abstract}

Keywords: Microfinance, Microfinance NGOs, Transformation, Financial Performance, Kenya

\section{Introduction}

Microfinance institutions are progressively being appreciated to play a key role in the fight against poverty especially in less developed economies (Armendáriz \& Vanroose, 2009; Bakhtiari, 2011; Khan, 2015). However, a large segment of the poor population still face difficulties to access financial services from most of the operating microfinance institutions (Hishigsuren, 2007; Bogan, Johnson \& Mhlanga, 2007; Armendáriz et al., 2009; Kar, 2011; Bogan, 2012; Adu, Anarfi \& Poku, 2014). Studies estimate that more than 500 million poor clients all over the world demand financial services (Helms, 2006). By end of 2010 microfinance institutions reported reaching over 200 million poor clients, women forming 82.3\% (Maes \& Reed, 2012). In most of the developing countries, microfinance institutions serve 5-20\% of the poor population (Hubka \& Zaidi, 2005). Reports show that more than $50 \%$ of the poor population in Kenya lack access to main stream banking system (Ali, 2015). The Financial Sector Deepening (FSD) reports that the main stream banking sector in Kenya serves less than 4 million people, which leaves majority of the economically active people to utilize the risky and expensive financial services and products of the informal and semiformal financial intermediaries (Ali, 2015).

Hence, there is still a need for microfinance to significantly scale up to achieve its potential by reaching out to billions of people, globally, who are currently not served by the sector (Herrmann-Pillath \& Schicks, 2007). However, limited capital and lack of loanable funds are explained to be main challenges facing the efforts of the microfinance institutions to deepen its outreach performance to a larger group of clients at the bottom of the pyramid (Chijoriga, 2015). 
This is because majority of the operating microfinance institutions are NGOs depending largely on limited and competitively available donor funds and government subsidies to provide the financial services and products to their clients at low cost(Baruah, 2010; Louis \& Baesens, 2013; D’Espallier, Goedecke, Hudon, \& Mersland, 2017; Amin et al., 2017). Therefore, microfinance NGOs are required to seek for alternative sources of soliciting funds for their financial sustainability and deepen outreach performance (Hoque, Chishty \& Halloway, 2011; Quayes \& Hasan, 2014). This has led some of the microfinance NGOs to be commercialised or transformed into formally regulated microfinance institutions (Fehr \& Hishigsuren, 2006; Sarma, 2011; Quayes et al., 2014).Transformation is claimed to enable the microfinance NGOs have access to more diverse sources of funds including deposits, equity and debt from commercial banks (Ledgerwood \& White, 2006; Khan, 2008; FSD-Kenya, 2012).

\subsection{Statement of the Problem}

Similar to the rest of the world, the microfinance sector in Kenya has experienced some microfinance NGOs transformed into regulated microfinance institutions (RMFIs) such as Sidian Bank, Faulu Microfinance Bank Limited and Kenya Women Microfinance Bank Limited. The literature on the transformation of microfinance NGOs is enormous (Olivares-Polanco, 2005; Ledgerwood et al., 2006; Hartarska \& Nadolnyak, 2007; Frank, Lynch \& Schneider-Moretto, 2008; Quayes, 2012; Wagenaar, 2012; Kar, 2013; Kipesha, 2013), however, results with regard to several different indicators used to measure financial performance are mixed or even contradictory (Kyereboah-Coleman \& Osei, 2008). Moreover, empirical studies on the effects of transformation on financial performance of microfinance NGO in Kenya are very rare. It is in the view of this background that this study considered it appropriate to examine the effects of transformation on financial performance of microfinance NGOs in the context of Kenya.

\section{Literature Review}

\subsection{Theoretical Review}

This study is anchored on dynamic capabilities view which was first documented by Teece (1990). Dynamic capabilities view contends that possessing heterogeneous and inimitable bundle of resources does not necessarily means that the organisation will be able to maintain its superior performance in the long-term but the ability of the firm to cope with the dynamic nature of resources and capabilities systems and their ever changing relationship (Grobler, 2007). Therefore, dynamic capabilities view explains the dynamic interactions between the environment of the firm and the essential capability building for sustainable competitive advantage (Zaidi \& Othman, 2012). Dynamic capabilities view was chosen to guide this study because it explains the changes that are taking place in the firm which consequently necessitates changes in the nature of the resources that are acquired and utilized by microfinance institutions and hence determines the performance of the firm.

The study applied also the life cycle theory to explain the theoretical relationship between the transformation of microfinance NGOs and financial performance. The life cycle theory explains the of institutional development and process of change in the organisations arguing that organisations are entities that share processes similar to those of any human's psycho social development (Van de Ven \& Poole, 1995; Bayai \& Ikhide, 2016b). In its life cycle development, a microfinance institution passes through start up stage, growth stage and maturity stage. The life cycle theory postulates that capital funding for microfinance institutions are associated with their respective stage of institutional development (Farrington \& Abrams, 2002). The diverse changes that are taking place in the microfinance institution at different stages in its development necessitate divergent sources of funding for its operations and sustainability (Bogan, 2012).

Furthermore, the study reviewed the Welfarist and Institutionalist lending models which provide the theoretical arguments on the best way of providing financial services and products to the poor. The Welfarist lending model focus on the poverty alleviation among the clients of the microfinance institution (Morduch, 2000). The Welfarists insists that the performance of a microfinance institution should be evaluated by looking on the changes caused to the welfare of its clients (Olivares-Polanco, 2005). This lending model aims at ensuring expansion of outreach performance of the microfinance institution by measuring the extent to which the program reaches the core poor clients. This school of thought refers to NGOs or co-operatives that believe microfinance is an intervention that should be engaged to allow the core poor have access to financial services and products. The Institutionist lending model, on the other hand, targets on having financially sustainable institutions and more clients reached by the microfinance institution as the priority (Woller et al., 1999). 
The proponents of the institutionalist lending model believe that the microfinance promise can be achieved by creating sustainable institutions. Therefore, this model emphasises the use of market approach in the delivery of microcredit for the microfinance institutions (Bassem, 2012).

\subsubsection{Commercial Sources of Capital and Performance of Microfinance Institutions}

The term commercial or private capital denotes all personal financial assets available for use and investment by any business but required to be paid for at a profit (de Sousa-Shields et al, 2004). Access to commercial sources of capital, therefore, entails the ability of the microfinance institutions to utilize all private financial resources such as debt and equity sources for the growth and expansion of its financial products and services to its clients (Ledgerwood et al., 2006). Microfinance NGOs have not been successful at accessing commercial sources of capital funding because they are not regulated (Bogan et al., 2007). Commercial banks have been lending only the net worth of the microfinance NGOs which has hindered the sustainability and outreach expansion of the organisations (Campion \& White, 1999). Conversion into a regulated microfinance institution guarantees payback of the borrowed fund and investments to the commercial lenders such as banks as well as investors and depositors (Ledgerwood et al., 2006). These microfinance NGOs have transformed their capital structures from one that depends largely on donor funding and subsidies to a capital structures that integrates commercial sources such as loans at market rates and equity funding (Campion \& White, 2001; Charitonenko, 2003; Khan, 2008; Cull, Demirgüç-Kunt \& Morduch; 2009).

Several benefits accrue to the microfinance institution from utilizing commercial capital funding. Commercial sources of capital funding offer more opportunity for the microfinance institution to leverage its equity base more than it can as an NGO (Ledgerwood et al., 2006). Leveraging enables the microfinance institution to intermediate more and diversified sources of cheaper funding including deposits from microenterprise, clients and larger commercial investors, interbank loans, central bank credit facilities and international capital markets for the rapid portfolio growth and ultimately reach more clients (Campion et al., 2001; Shah, 2011; Tchuigoua, 2014). According to Ledgerwood et al. (2006) and Felipe (2011), rapid portfolio growth will enable the microfinance institutions to enjoy economies of scale, consolidate financial performance and expand outreach to its clients. Capital funding from commercial sources of such as debt and equity funding increases the capital base of the transformed microfinance institution and in turn enables the institution to expand the breadth outreach performance (Fernando, 2004; Abrar \& Javaid, 2016). Donor funds may be ideal for the microfinance institution at the infant stage but as the institution grows quickly due to increasing demand of small scale financial services and products by the poor, extra source of capital that is guaranteed and stable could be required (Campion et al., 2001). The best approach to ensure rate of growth of microfinance NGOs and keep pace with the ever increasing demand of small scale financial services and products is to gain access to external sources of capital funding through transformation (Campion et al., 2001; Gallardo, 2002).

\subsubsection{Mobilization of Savings and Performance of Microfinance Institutions}

Basically, microfinance NGOs were introduced to enable access to financial services and products to the poor and underprivileged section of the population especially women who constitute the largest proportion of the poor (Asian Development Bank, 2000; Marr \& Tubaro, 2013). The demand for financial services by the poor is ever increasing which creates a need for microfinance institutions to grow and expand their services. However, the growth and expansion of microfinance NGOs programs is inhibited by limited capital, which largely depends on donor funds and subsidies (McGuire \& Conroy, 2000). Possible sources of funding available to microfinance institutions to capitalize loan portfolio include mobilization of savings (among others) from the public. But regulatory policies in most countries do not allow financial intermediaries that are not regulated to take savings from the public due to lack of insurance mechanisms of those savings (McGuire et al., 2000; Campion et al., 2001; CGAP, 2005; Pytkowska, 2006; Frank et al., 2008; Baruah, 2010). According to McGuire et al. (2000), savings mobilization from the public is an important financial intermediation and stable source of capital base that most microfinance institutions could use to secure funds that supplements the limited donations and subsidies.

Some microfinance NGOs have transformed into regulated microfinance to be able to take deposits from the public with the aim of building a stable source of capital base (Elser, Hannig \& Wisniwski, 1999; Campion et al., 2001; CGAP, 2005; Frank, et al, 2008). Ability to mobilize savings from the public contributes both to meeting the effective demand of financial services by the poor and enhancing long-term sustainability of the transformed microfinance institution (Ledgerwood, 1999; Elser et al, 1999). 
Acording to Mwizarubi, Singh, Mnzava \& Prusty (2016), mobilization of savings from the public constitute the most significant drive of financial sustainability among other sources of capital funding for microfinance institutions. Robinson (2004) defines savings as a way of securing future consumption at any time, either in cash or in kind. It is a disposable or portion of the income that is not spent on consumption for the purpose of future consumption or investment (Gardiol, 2004). Savings can broadly be categorized into two types, namely voluntary/flexible savings and forced/compulsory savings (Bass \& Henderson, 2000; CGAP, 2005; Olivier, 2011; Bruno and Khachatryan, 2011). Voluntary savings refers to savings held in the financial institutions but not aimed to access credit from the institution. A large number of clients in microfinance institutions prefer voluntary savings products which in turn enables the firm to get more funds. (Bass et al., 2000). Forced and/or compulsory savings refer to the contributions to the savings account as a precondition to gaining access to loans (Bass et al., 2000; CGAP, 2005; Olivier, 2011; Bruno et al., 2011).

Several benefits accrue to the microfinance institutions from mobilization of savings from the public. Mobilization of savings from the public creates safe and sound microfinance institutions where clients deposit their funds and expect to get profit upon withdrawal. Savings mobilization is the action of capturing voluntary deposits from the public, protecting, managing and using deposits to fund loan portfolios (Branch \& Klaehn, 2002). Mobilization of savings from the public is now by far the key source of funding for most of the microfinance institutions (Maisch, Soria \& Westley, 2006; Abrar et al., 2016). Savings from the public provides a desired independent source of fund basically for the provision of credit facilities in microfinance institutions (Abrar et al., 2016).

A large number of the poor prefer to use savings services and products of the microfinance institutions over credit to take precautions of the future financial obligations. As a result, mobilization of savings from the public expands and deepen outreach performance for the microfinance institutions (Bass et al., 2000; Campion et al., 2001). Similarly, stakeholders and even donor agencies widely believe that mobilization of savings from the public offers to the microfinance institutions a stable source of funds than funds from the donors which in turn helps to expand funding operations and benefit poor borrowers (Mukherjee et al., 1998; Bass et al., 2000; Campion et al., 2001; Maisch et al., 2006; Hoque et al., 2011).

According to Felipe (2011), mobilization of savings from the public enable microfinance institutions to have access to more diversified funding base to support the long-term portfolio growth. Mobilization of savings from the public also enables self-sustainability and growth for the microfinance institution being cheaper sources of funds for the microfinance institutions as compared to other commercial sources of funds (Elser et al., 1999; Morduch, 2000; Bass et al., 2000; Maisch et al., 2006; Hoque et al., 2011). The main concern for the savings mobilization is the trade-off between a cheaper source of funds for the microfinance institution and the cost of mobilizing and administering small savings that are frequently very high (Mukherjee et al., 1998; Morduch, 2000).

Mobilization of savings from the public enables microfinance institutions an opportunity to offer more financial products and services beyond their previous focus on credit by creating new financial services and products to a large number of clients (Maisch et al., 2006; Frank et al., 2008). Mobilization of savings from the public enables microfinance institutions to provide the clients with several benefits including potential of liquidity, savings for investment and interest earnings, less transactions costs resulting from the economies of scale reaped by the institution and convenience to savings products (Campion et al., 2001). Mobilization of savings from the public minimizes the need for other commercial sources of capital funding and builds also a more dependable and stable sources of capital to the microfinance institutions (Campion et al., 2001). Mobilization of savings from the public also creates potential borrowers for the microfinance institutions. Morduch (2000) asserts that, today's depositors are the tomorrow's borrowers.

\subsection{Empirical Review}

Various researchers including Hartarska (2005), Mersland and Strom (2007), Mori and Olomi (2012) and Bakker, Schaveling and Nijhof (2014) report that different indicators such as debt to equity ratio and debt to asset ratio can be used to study the relationship between commercial capital funding and performance of microfinance institutions. Sekabira (2013) studied the effects of capital structure on financial performance of 14 sampled microfinance institutions in Uganda using five years panel data from 2004 to 2008. The author noted that the selected measures of capital structure are essential in the sustainability of microfinance institutions. 
Results of the study revealed that there was an inverse relationship between debt and grants measures of capital structure and financial performance. The more the microfinance institutions is financed with share capital the higher the sustainability which lead the study recommend microfinance institutions to focus less on debt and grants and make use of equity financing for long-term financial sustainability.

Bogan (2012) investigated the effects of changes in financing on the performance of microfinance institutions. Regression results showed that the larger microfinance institutions are financed by grants the lower their financial performance measured by financial self-sufficiency would be. Kinde (2012) studied the determinants of financial sustainability of microfinance institutions and applied quantitative research approach and multivariate regression analysis using balanced panel data set of fourteen microfinance institutions in Ethiopia for nine years. The author found that there was no significant relationship between capital structure measured by both debt to equity and equity to total capital and indicators of financial sustainability of microfinance institutions in Ethiopia. Bogan et al. (2007) used life cycle theory to study the association between measures of capital structure and indicators of financial sustainability of microfinance institutions in Africa, Asia, Europe, America and South Asia. Findings from the regression analysis of panel data showed that financial performance in microfinance institutions is not associated with institutional age but rather significantly influenced by the capital structure and funding instruments which specifically indicated that an increase in the use of grants significantly reduces the financial sustainability of microfinance institutions. Bayai et al. (2016a) conducted a conceptual review on the link between financing of microfinance institutions and indicators of financial sustainability. The authors noted that donor funding is losing control as a popular microfinance institution financing option. Instead, more focus is on debt which has shown to improve financial sustainability of microfinance institutions. Furthermore, the authors found that mobilization of savings from the public increases sustainability of microfinance institutions.

Mwizarubi et al. (2016) examined the influence of the attributes of capital structure such as deposit mobilization, shareholders equity and selling shares in stock markets on the financial sustainability of microfinance institutions in Tanzania. The study applied quarterly time series data ranging from 1997 to 2014. The authors found that financial sustainability of microfinance institutions is strongly influenced mostly by mobilization of savings from the public. Tuyishime, Memba and Mbera (2015) used a census survey to study effects of mobilizing deposits from the public on indicators of financial performance of commercial banks in Rwanda. The authors used secondary and primary data from a population of 27 staff of Equity Commercial Bank and found that there is a positive association between interest rates on deposits and the level of deposits which consequently determines the profitability in commercial banks.

\subsection{Summary and Research Gap}

The theoretical and empirical reviewed literature discussed above underscores the importance of transformation of microfinance NGOs on financial performance. However, this study has noted that there is little documented evidence that explains effects of transformation on financial performance of microfinance NGOs in Kenya especially using access to commercial sources of capital and mobilisation of savings from the public as measures of transformation. Moreover, transformation of microfinance NGOs into regulated microfinance institutions is a time process. Several of the reviewed previous studies on the performance of the transformed microfinance NGOs in Kenya were noted to have been done on institutions that were either just been transformed or still in the transformation process and therefore the results and findings developed therefrom may be misleading. This study covers this gap by analyzing microfinance NGOs that have completed the transformation process andoperates as regulated financial intermediaries at least for a period of five years.

\section{Methodology}

This study used positivism research paradigm of the objectivism continuum to analyse the effects of transformation of microfinance NGOs on financial performance. Objectivism continuum was applied to enhance the researcher to study the area independently by disengaging researcher's influence on the study (Johnson \& Duberley, 2000). This research collected numerical data and used quantitative data examination methods to study the cause-effect relationship between transformation of microfinance NGOs and financial performance. The study was undertaken to investigate effects of transformation on financial performance of microfinance NGOs in Kenya. Therefore, the population for this study included commercial and microfinance banks that have undergone transformation from microfinance NGO. 
By June 2015, the Kenyan banking sector was comprised of two (2) commercial banks that were transformed from microfinance NGO, namely Sidian Bank and Jamii Bora Bank (CBK Annual Report, 2015). The sector was also comprised of four (4) microfinance banks (MFBs) that were transformed from microfinance NGO including Faulu Microfinance Bank Ltd, Kenya Women Microfinance Bank Ltd, SMEP Microfinance Bank Ltd and Uwezo Microfinance Bank Ltd.The study has taken a census survey whereby all commercial and microfinance banks that have undergone transformation from microfinance NGO were involved in the investigation. Therefore the unit of analysis for this study had six (6) financial institutions including Sidian Bank, Jamii Bora Bank, Faulu Microfinance Bank Ltd, Kenya Women Microfinance Bank Ltd, SMEP Microfinance Bank Ltd and Uwezo Microfinance Bank Ltd.

In this research, the study applied secondary data that was collected from the Microfinance Information Exchange (Mix) Market database on the selected indicators of transformation and financial performance of the sampled microfinance institutions. The Mix Market is a non-profit organisation based in United States that has the most comprehensive, reliable and publicly available audited financial and outreach performance information on institutions that offer microfinance services and products to the poor, all over the world (Shu\& Oney, 2014). Websites of the surveyed commercial and microfinance banks were also visited to access published audited financial and income statements to complement on the missing data collected from Mix Market. Moreover, individual microfinance institutions were contacted to get updated and detailed information.

The study used statistical ratios analyses to establish the association between transformation of microfinance NGOs and financial performance using unbalanced panel dataset of 6 cross sections (commercial and microfinance banks) for 19 years extending from 1997 to 2015. The period of investigation for this study was suggested to start from the year 1997 so as to give allowance for the study to have data before the transformation of some of the cross sections. Likewise, the collection of data ended in the year 2015 to allow the study to have complete annual data for all the cross sections in the latest year of data availability and accessibility during data collection. Unbalanced panel data resulted from the fact that the time series data collected and applied in this study was not the same for all the six cross sections.

The study preferred to use panel data because of its potential for the analysis of causal relationships between transformation and financial performance in the transformed microfinance NGOs (Berrington, Smith \& Sturgis, 2006). Panel data can be analysed using fixed effects model or random effects model (Gujarat, 2009; Park, 2015). Hausman test was applied to make a decision on whether to use fixed effects regression model or random effects regression model for the analysis of panel data with the null hypothesis that the individual specific effects and the regressors in the model are not correlated. A test with a significant probability statistic value $(\mathrm{p}<0.05)$ indicated that fixed effect regression model was appropriate to analyse the panel data, otherwise random effect regression model was applied.

Shapiro-Wilk test and Kernel density plots were applied to examine the normality assumption for the distribution of the study variables. Collinearity diagnostic routine using pairwise correlation was performed in the linear regression model to detect existence of multicollinearity problem in theselected indicators of transformation of microfinance NGOs. Variance Inflation Factor (VIF) as well as tolerance statistic values were also used to check for multicollinearity. The rule of thumb used was that, if the resulting VIF value lies between 1 and 10 then there is no multicollinearity problem (Myers, 1990; Bowerman \& O'Connell, 1990). Tolerance value was obtained by subtracting the value of $\mathrm{R}^{2}$ from 1 (O'brien, 2007). Variables with tolerance statistic values less than 0.1 were considered as having multicollinearity problem (Tabachnick \& Fidell, 2001; Katz, 2011).

Heteroskedasticity test using Breusch-Pagan Test/Cook-Weisberg was deployed to examine the existence of constant variance among the range of predictor variables/error terms i.e. $\operatorname{Var}\left(\mathrm{u} / X_{1}, \ldots, X_{k}\right)=\sigma^{2}$. The study performed also the Wooldridge test to check if the error terms from consecutive time periods are uncorrelated (Studenmund, 2013), that is, the error term for period $t-1$ is uncorrelated with the error term for period $t$. Robust consistent standard errors approach was carried out in the regression models to clear all possible heteroscedasticity and autocorrelation problems in the models (Long \& Ervin, 2000; Hayes \& Cai, 2007). To check whether the values of response variable for two different periods are not related with each other (i.e. stationarity test), the study used Fisher test for panel unit root using an augmented Dickey-Fuller (ADF) to examine existence of unit root in the dependent variable, i.e. financial performance. A significance level (alpha) of $\mathrm{p}<0.05$ was applied in this study. The study rejected the null hypotheses if the calculated test statistic value was significant, i.e. falls below the chosen significance level $(\mathrm{p}<0.05)$. 


\subsection{The Model}

To analyse the effects of transformation of microfinance NGOs on financial performance, the following basic panel data regression model was applied:

Where:

$$
Y_{i, t}=\alpha+\beta X^{\prime}+u_{i, t} \text { where } i=1 \ldots N \text { and } t=1 \ldots T
$$

$i$ stands for cross section dimension i.e. individual microfinance institutions and $t$ stands for the period of time dimension. $\alpha$ is scalar, $\beta$ is a $K x 1$ vector and $X_{i, t}$ is a vector of selected indicators of transformation of microfinance NGOs. Beyond the institution-specific variables identified, the study believed that the individual institutions might have other unobserved characteristics that differentiate them from each other. To estimate the panel data model that takes care of such unobserved individual-specific effects, this study applied a one way error component model and re-write equation (1) as follows:

$$
Y_{i, t}=\alpha+\beta X^{\prime}+\mu_{i}+\mathrm{v}_{i, t}
$$

Where:

$u_{i, t}=\mu_{i}+\mathrm{v}_{i, t}$ and $\mu_{i}$ stands for the unobserved heterogeneity time-invariant institution specific effect and $\mathrm{v}_{i, t}$ denotes the remainder of the disturbances.

\subsection{Model Specification}

Variables and indicators included in the empirical model were selected with reference to the reviewed literature and availability of data. This study aimed to test and examine the effects of transformation on the level of financial performance of microfinance NGOs, that is, transformation enables the regulated microfinance institutions to earn higher return on assets, higher return on equity and higher operational self-sufficiency. Following the recent literature, the following econometric panel data model with aggregated time effects was estimated:

$Y_{i, t}=\alpha_{i}+\delta_{i} X_{i, t}+\beta_{i} \operatorname{Trans}_{i, t}+\varepsilon_{i, t}$

Where:

$Y_{i, t}$ is the response variable i.e. financial performance of the microfinance bank ${ }_{i}$ at time ${ }_{t}$, with $\mathrm{i}=1, \ldots, 6, \mathrm{t}=$ $1, \ldots, 19, \alpha_{\mathrm{i}}$ is the value of a constant term, $X_{i}$ represent control variables for the microfinance bank ${ }_{i}$ at time ${ }_{t}$ with coefficient $\delta_{i}$, Trans ${ }_{i, t}$ represent the transformation indicators of the microfinance institution ${ }_{i}$ at time ${ }_{t}$ with a coefficient $\beta_{i}$, and $\varepsilon_{i, t}$ is the error term. Transformation indicators will include debt to equity ratio, debt to asset ratio and deposits to total assets ratio.

\subsection{Explanation and Operationalization of the Study Variables}

Transformation of microfinance NGOs in this study was assessed by change in financing structure of the microfinance institution (Hoque et al., 2011; Dawar, 2014). Hence, transformation was proxied by financing structure indicators i.e. debt to equity ratio, debt to asset ratio and deposits to total assets ratio (Bogan et al., 2007; Chahine et al., 2010; Bogan, 2012; Kodongo, Mokoaleli-Mokoteli and Maina, 2014; Abrar \& Javaid, 2016). Debt to equity ratio indicates the percentage of borrowed fund used by the microfinance institution as a source of capital funding relative to its equity (Kyereboah-Coleman, 2007; Kipesha \& Zang, 2013; Abrar et al., 2016). Higher values of debt to equity ratio indicate that the capital of the microfinance institution is highly financed by debt than equity and therefore shows higher risks to lenders (Maina \& Ishmail, 2014). Thus, by and large, the study expected a negative effect of debt to equity ratio on the indicators of financial performance (Sekabira, 2013; Quayes, 2012; Quayes et al., 2014; Javed, Rao, Akram, \& Nazir, 2015; Quayes, 2015).

Debt to asset ratio looks at the amount of funds borrowed by the microfinance institution in relation to its total assets (Bogan et al., 2007; Dawar, 2014; Abrar et al., 2016). If the capital structure of the microfinance institution is highly financed by debt then the value of debt to assets ratio will be higher. Higher composition of debt relative asset in the financing structure of the microfinance institution is associated with low financial performance (Sekabira, 2013; Maina et al., 2014). Thus, the study expected a negative effect of debt to asset ratio on the indicators of financial performance of microfinance institutions. Deposits to total assets ratio indicates the segment of the capital structure of the microfinance institution that is financed by public savings (Bogan, 2012; Awaworyi et al., 2014). Deposits provide cheaper sources of funding and as such lowers the cost of operations for microfinance institutions and in return increase the financial sustainability of the microfinance institutions through increased profitability (Helms, 2006; Bayai et al., 2016a). Therefore, the study expected a positive effect of deposits to total assets ratio on the indicators of financial performance (Awaworyi et al., 2014). 
Financial performance in microfinance institutions has conventionally been assessed by using the same financial ratios applied in the performance of traditional banks (Mustafa \& Saat, 2013). To remain consistent and for the purpose of comparability with previous findings, this study used overall financial performance ratios as indicators of financial performance of the transformed microfinance NGOs. The common indicators used to evaluate the overall financial performance in microfinance institutions literature include return on assets (ROA), return on equity (ROE) and operational self-sufficiency (OSS) (MixMarket, 2006; Chahine \& Tannir, 2010; Rahman \& Mazlan, 2014).

ROAdenotes a commercially desirable rate of return at which the microfinance institution is able to utilize market capital funding and the possibility of becoming a regulated microfinance institution (Adhikary \&Papachristou, 2014). A positive return on assets value indicates that the microfinance institution is financially sustainable (Bassem, 2012). Return on equity (ROE) also measures the overall profitability by looking at the efficiency of the microfinance institution to generate a return of each shareholder equity fund (Dissanayake, 2014; Rahman et al., 2014). It is an accounting ratio that measures common stock owner's interest. A microfinance institution is considered to be financially sustainable if generates positive return on equity values (Bassem, 2012). OSS is an accounting ratio which provides information that indicates whether the microfinance institutions is earning enough revenue that can be used to clear the total costs (Hartarska et al., 2007; Schäfer \& Fukasawa, 2011; Quayes, 2015). A microfinance institution with OSS value of $100 \%$ or more indicates that the microfinance institution is earning enough revenue that covers total costs (Bassem, 2012; Quayes, 2015).

Furthermore, thestudy used institutional size variable (proxied by the total value of assets that the microfinance institution owns) to control for differences in the size of the microfinance institutions. Larger microfinance institutions have higher chances of enjoying economies of scale and scope which in turn enhances the financial performance than small ones (Ndambu, 2011; Singh, Goyal \& Sharma, 2013). In order to maintain consistency with other ratios in the analysis and avoid deflation of assets, this study used natural logarithm of institution's total assets. Therefore, the study expected a positive effect of institutional size on the indicators financial performance of microfinance institution (Quayes, 2012).Likewise, the study used institutional age variable (proxied by total number of years the microfinance institution has been in operation) to control for the differences in time the institutions have been in operation. Institutional age controls for learning effect among the microfinance institutions especial on financial performance (Adhikary et al., 2014). Older microfinance institutions are likely to be more experienced and utilize their resources efficiently which in turn will enable them to achieve higher financial and outreach performance than new ones (Hermes, Lensink \& Meesters, 2011; Singh et al., 2013). Thus, the study expected a positive effect of institutional age on both financial performance indicators of microfinance institutions (Okumu, 2007). The study adopted the definition and categories of microfinance institution's age as provided by Mix Market (i.e. new, young and mature) and applies dummy variables to attach numerical values to the strings (Bogan et al., 2007).

\section{Empirical/Econometric Results and Discussions}

The presentation of the econometric results and discussions of effects of transformation on financial performance is done in three different sections based on the selected measures of financial performance i.e. return on assets, return on equity and operational self-sufficiency. Table 4.1 presents summary statistics of the indicators of transformation and financial performance used in the analysis. It can be noted that the average profitability performance of the surveyed institutions is very low indicated by the -5.9 percent and -24.7 percent values of return on assets and return on equity respectively. However, the microfinance institutions appear to be operationally sustainable since the reported average operational self-sufficiency value is 1.05 . The average value for debt to equity ratio of the microfinance institutions is 3.49 with a standard deviation of 2.73 and the average value for debt to asset ratio is 0.6 that has a standard deviation of 0.21 . On average, the microfinance institutions had a $44.6 \%$ capital financing from deposits.

Table 4.1 Summary Statistics

\begin{tabular}{|l|l|l|l|l|l|}
\hline Variable & Obs. & Mean & Std. Dev. & Min & Max \\
\hline ROA & 91 & -.0592209 & .3813839 & -3.36 & .0836 \\
\hline ROE & 91 & -.246844 & 2.593523 & -24.62 & .4674 \\
\hline OSS & 85 & 1.05277 & .2166718 & .3428 & 1.4051 \\
\hline DER & 92 & 3.490009 & 2.73025 & .07 & 14.59 \\
\hline DAR & 92 & .6793889 & .2125856 & .0678703 & .9358397 \\
\hline DTAR & 59 & .4469037 & .1584011 & .0111036 & .7472536 \\
\hline
\end{tabular}




\subsection{Transformation of Microfinance NGOs and Return on Assets}

The study used random effects regression model with consistent robust standard errors approach to analyse the effects of the selected indicators of transformation of microfinance NGOs on financial performance as measured by return on assets (ROA). To establish the actual regressors, the study applied backward stepwise regression method with a 0.1 significance level for the coefficients where DTAR was removed and the final model used is given below:

$\operatorname{lnROA}_{i, t}=\beta_{0}+\beta_{1} \ln D E R_{i, t}+\beta_{2} \ln D A R_{i, t}+\beta_{3} \ln \operatorname{Assets}_{t}+\beta_{4} \ln A g e_{t}+u_{i, t}$

Where:

$\ln R O A_{i, t}$ is the natural logarithm of return on assets (dependent variable), $\beta_{0}$ is the value of a constant term, $\ln D E R_{i, t}$ stands for natural logarithms of debt to equity ratio, $\ln D A R_{i, t}$ is the natural logarithm of debt to asset ratio, lnAssets represents the natural logarithm of assets, lnAge stands for the natural logarithm of age, $\beta_{1-4}$ represents the coefficients of the independent variables, and $u_{i, t}$ is the error term. All variables are for the microfinance bank ${ }_{i}$ at time $_{t}$ with $\mathrm{i}=1 \ldots 6$, and $\mathrm{t}=1 \ldots 19$

The statistical significance test revealed a very significant overall Wald chi2 $(4)=215.95$, Prob $>$ chi2 $=0.0000$. Therefore, the study rejected the null hypothesis that all coefficients of the variables (except the intercept) that are not significant individually are equal to zero (Wooldridge, 2002; Bassem, 2012) and concluded that at the 0.05 level, the estimated regression model was significant at establishing the effects of transformation of microfinance NGOs on return on assets indicator of financial performance. The R-squared values indicated that using return on assets as an indicator of financial performance, the variations that can be explained by transformation is higher from one microfinance institution to the next than within a microfinance institution. However, overall, the estimated regression model explains $35.44 \%$ of the variations in the return on assets measure of financial performance using the selected independent variables (see Table 4:2).

Econometric results indicated a very significant effect of debt to equity ratio on return on assets. As expected, the study noted a statistically adverse coefficient that is significant at the 0.05 level. Results show that for one unit increase in debt to equity ratio, return on assets is anticipated to decrease by 0.0546 units, when the remaining variables in the model are kept constant. This means that when a microfinance institution moves to commercial debt, its profitability, measured by return on assets, decreases. This result affirms the findings in the study of Dawar (2014), Maina and Ishmail (2014) and Ronoh and Ntoiti (2015) who evidenced a negative and significant effect of debt to equity ratio on financial performance. On the contrary, the study differs with the findings of Dissanayake (2014), Abrar and Javaid (2016) and Prakash (2016) who verified that the more the microfinance institution is financed by debt, the more profitable and sustainable the institution becomes and this could possibly be resulting from larger sample used by the authors.

The outcome of the regression analysis, further indicated that there is a statistically significant effect of debt to asset ratio on return on assets. Unexpectedly, the study noted a direct coefficient that is significant at the 0.05 level. Results show that for one unit increase in debt to asset ratio, return on assets is anticipated to increase by 0.1584 units, when the remaining variables in the model are kept constant. This finding suggests that leveraging, proxied by debt to asset ratio, increases return on assets measure of profitability in microfinance institutions. This outcome is broadly in harmony with the findings of Kodongo et al. (2014) and Abrar et al. (2016) who evidenced that the more leveraged (higher debt to assets ratio) microfinance institutions have higher profitability (return on assets). However, evidence of this study is in contrast with the findings of Bogan (2012).

Econometric results indicated that institutional size significantly affected return on assets. As expected, the coefficient of institutional size, proxied by number of assets owned by the institution is positive and statistically significant at the 0.05 level. Results show that for one unit increase in the institutional size, return on assets is anticipated to increase by 0.0088 units, when the remaining variables in the model are kept constant. This implies that microfinance institutions with relatively more assets have higher return on assets measure of financial performance. This result affirms the findings developed in (Cull et al., 2007; Hartarska et al., 2007; Dawar, 2014; Adhikary et al., 2014; Tchuigoua, 2015; Akben-Selcuk, 2016; King'ori, Kioko \& Shikumo, 2017) which suggest that larger microfinance institutions earn higher profitability because they enjoy higher reputation, economies of scale and have the ability to use significant effect in products and influence markets. On the contrary, Bassem (2012) and Abrar et al. (2016) found a negative effect of institutional size on return on assets in microfinance institutions. 
Unexpectedly, results revealed that institutional age has an adverse non-significant effect on return on assets. The coefficient of institutional age is negative and statistically insignificant at the 0.05 level. Results show that for one unit increase in institutional age, return on assets is anticipated to decrease by 0.0266 units, when the remaining variables in the model are kept constant. The non-significant coefficient in this model suggests that as the microfinance institution matures, the option for commercial sources of capital per se does not outshine profitability measured by return on asset. Probably, this could be explained by the failure of mature microfinance institutions to adjust to the changing competitive product and factor market place compared to the emerging institutions. This evidence is not in accordance with the suggestions of life cycle theory of institutional development. This result concurs with the findings of Dawar (2014). Interestingly, Bassem (2012), Adhikary et al. (2014) and Bayai et al. (2016a) found dissimilar results noting that the financial performance of new microfinance institutions is poor because of low technology, lack of sufficient capital, small client base and operational challenges.

Table 4:2 Random Effect Regression Model: Effects of Transformation on Return on Assets

\begin{tabular}{|c|c|c|c|c|c|c|}
\hline $\ln \mathrm{ROA}$ & Coef. $\mathrm{R}$ & Robust Std. Err. & $\mathrm{z}$ & $\mathrm{P}>|\mathrm{z}|$ & & \\
\hline $\operatorname{lnDER}$ & -.0545846 & .0112934 & & -4.83 & & 0.000 \\
\hline lnDAR & .158441 & .0367094 & & 4.32 & 0.000 & \\
\hline $\ln$ Assets & .0088125 & .0055549 & & 1.59 & 0.003 & \\
\hline $\ln A g e$ & .0265856 & .044003 & & 0.60 & 0.106 & \\
\hline cons & -.0440407 & .0774359 & & -0.57 & & 0.570 \\
\hline \multicolumn{2}{|c|}{ R-sq Within $=0.2932$} & Between $=0.9 ?$ & 336 & Over & $=0$ & \\
\hline
\end{tabular}

\subsection{Transformation of Microfinance NGOs and Return on Equity}

This study used random effects regression model with consistent robust standard errors approach to analyse the effects of the selected indicators of transformation of microfinance NGOs on financial performance as determined by return on equity (ROE). To establish the actual regressors, the study applied backward stepwise regression method with a 0.1 significance level for the coefficients where DTAR was removed and the final model used is given below:

$\ln R O E_{i, t}=\beta_{0}+\beta_{1} \ln D E R_{i, t}+\beta_{2} \ln D A R_{i, t}+\beta_{3} \ln \operatorname{lssets}_{t}+\beta_{4} \ln A g e_{t}+u_{i, t}$

Where:

$\ln R O E_{i, t}$ is the natural logarithm of return on equity (dependent variable, $\beta_{0}$ is the value of a constant term, $\ln D E R_{i, t}$ stands for natural logarithms of debt to equity ratio, $\ln D A R_{i, t}$ is the natural logarithm of debt to asset ratio, lnAssets represents the natural logarithm of assets, lnAge stands for the natural logarithm of age, $\beta_{1-4}$ represents the coefficients of the independent variables, and $u_{i, t}$ is the error term. All variables are for the microfinance bank ${ }_{i}$ at time $_{t}$. with $\mathrm{i}=1 \ldots 6$ and $\mathrm{t}=1 \ldots 19$.

A very significant overall Wald chi $2(4)=99.80$, Prob $>$ chi $2=0.0000$ was reported at the 0.05 level. Therefore, the study rejected the null hypothesis that all coefficients are equal to zero and concluded that the estimated regression model was significant at establishing the effects of transformation of microfinance NGOs on return on equity indicator of financial performance. The R-squared values indicate that using return on equity as a measure of financial performance, the variations that can be explained by transformation is higher from one microfinance institution to the next than within a microfinance institution. However, overall, the estimated regression model explains $21.70 \%$ of the variations in the return on equity using the selected independent variables (see Table 4:3). Regression results indicated a significant effect of debt to equity ratio on return on equity. As expected, the coefficient is negative and statistically significant at the 0.05 level. Results show that for one unit increase in debt to equity ratio, return on equity is anticipated to decrease by 0.1423 units, when the remaining variables in the model are kept constant. This means that highly leveraged (high debt to equity ratio) microfinance institutions have poor financial performance measured by return on equity. This evidence is in line with findings developed in Dissanayake (2012) and Dawar (2014). However, the findings of this study are at odds with the evidence found in the study of Berger \& Di Patti (2006), Maisch et al. (2006), Abrar et al. (2016) and Omare (2017) who found a positive relationship between debt to equity ratio and return on assets and concluded that firms with higher debt to equity ratio have higher profitability measured by return on equity. 
Econometric results exhibited a very significant effect of debt to asset ratio on return on equity. Surprisingly, the coefficient is positive and statistically significant at the 0.05 level. Results show that for one unit increase in debt to asset ratio, return on equity is anticipated to increase by 0.3026 units, when the remaining variables in the model are kept constant. This means that highly leveraged (high debt to asset ratio) microfinance institutions attain greater outreach and thus higher premium from credit advanced that translates into income flow and thus profitability for the microfinance institutions. This result concurs with the findings in the study of KyereboahColeman (2007) and Omare (2017) who found that debt to asset ratio influences profitability of the firm. However, this evidence contrasts with the findings of Kodongo et al. (2014), which could be explained by the fact that the authors have used a sample of listed firms in Kenya.

Institutional size reported a significant effect on the return on equity. As expected, the coefficient is positive and statistically significant at the 0.05 level. Results show that for one unit increase in microfinance institution size, return on equity is anticipated to increase by 0.0575 units, when the remaining variables in the model are kept constant. This result implies that large microfinance institutions have slightly higher financial performance measured by return on equity. This could possibly be due to the fact that larger microfinance institutions usually are more diversified, have relatively more capacities and more resources. This result concurs with the evidence found in the study of Abrar et al. (2016), Omare (2017) and Akben-Selcuk (2016). However, this result is in contrast with the findings in the study of Kodongo et al. (2014).

Econometric results indicated that institutional age inversely affected the return on equity. Unexpectedly, the coefficient is negative and statistically insignificant at 0.05 level. Results show that for one unit increase in microfinance age, return on equity is anticipated to decrease by 0.0379 units, when the remaining variables in the model are kept constant. This finding suggests that older microfinance institutions tend to have poor financial performance measured by return on assets which could be caused by "inertia effects" which causes microfinance institutions to become inflexible and face difficulties to cope with the rapidly changing business environment in which they operate. However, the non-significant coefficient in this model implies that aging and as the microfinance institution opt for commercial sources of capital does not compromise the financial performance measured by return on equity. This result is in line with the findings in the study of Abrar et al. (2016) and Akben-Selcuk (2016).

\section{Table 4:3 Random Effect Regression Model: Effects of Transformation on Return on Equity}

\begin{tabular}{rccccc}
\hline & & & \\
$\ln R O E$ & Coef. & Robust Std. Err. $\quad \mathrm{z}$ & $\mathrm{P}>|\mathrm{z}|$ & \\
\hline $\operatorname{lnDER}$ & -.142274 & .0537629 & -2.65 & 0.008 \\
$\operatorname{lnDAR}$ & .3025547 & .0635741 & 4.76 & 0.000 \\
$\ln$ Assets & .0574576 & .0284536 & 2.02 & 0.043 \\
$\ln$ Age & -.037934 & .1118137 & -0.34 & 0.104 & \\
cons & -.6417994 & .3823889 & -1.68 & 0.093 \\
\hline R-sq Within $=0.2155$ & Between $=0.7768$ & \multicolumn{3}{c}{ Overall $=0.2170$} \\
\hline
\end{tabular}

\subsection{Transformation of Microfinance NGOs and Operational Self-Sufficiency}

This study used random effects regression model with consistent robust standard errors approach to analyse the effects of the selected indicators of transformation of microfinance NGOs on financial performance as measured by operational self-sufficiency (OSS). To establish the actual regressors, the study applied backward stepwise regression method with a 0.1 significance level for the coefficients where DTAR was removed and the final model used is given below:

$\operatorname{lnOSS_{i,t}}=\beta_{0}+\beta_{1} \ln D E R_{i, t}+\beta_{2} \ln D A R_{i, t}+\beta_{3} \ln \operatorname{Assets}_{t}+\beta_{4} \ln A g e_{t}+u_{i, t}$

Where:

$\ln O S S_{i, t}$ is the natural logarithm for operational self-sufficiency (dependent variable), $\beta_{0}$ is the value of a constant term, $\ln D E R_{i, t}$ stands for natural logarithms of debt to equity, $\ln D A R_{i, t}$ is the natural logarithm of debt to asset ratio, InAssets represents the natural logarithm of assets, lnAge stands for the natural logarithm of age, $\beta_{1-4}$ represents the coefficients of the independent variables, and $u_{i, t}$ is the error term. All variables are for the microfinance bank $_{i}$ at time ${ }_{t}$ with $\mathrm{i}=1 \ldots 6$ and $\mathrm{t}=1 \ldots 19$. 
The statistical significance test revealed a very significant overall Wald chi2 $(4)=297.49$, Prob $>$ chi2 $=0.0000$. Therefore, the study rejected the null hypothesis that all coefficients of the variables that are not significant individually are equal to zero and concluded that at the 0.05 level, the estimated regression model was significant at establishing the effects of transformation of microfinance NGOs on operational self-sufficiency indicator of financial performance. The R-squared values indicated that using operational self-sufficiency as a measure of financial performance, the variations that can be explained by transformation is higher within a microfinance institution than from one microfinance institution to the next. However, overall, the estimated regression model explains $34.07 \%$ of the variations in operational self-sufficiency using the selected independent variables (see Table 4:4).

Econometric results demonstrated that debt to equity ratio inversely affected the operational self-sufficiency. As expected, the coefficient is negative and statistically significant at the 0.05 level. Results show that for one unit increase in debt to equity ratio, operational self-sufficiency is anticipated to decrease by 0.2717 units, when the remaining variables in the model are kept constant. This implies that when a microfinance institution opts for commercial debt, its sustainability measured by operational self-sufficiency declines. In other words, this means that less leveraged microfinance institutions have better financial performance measured by operational selfsufficiency. The increased use of commercial debt rises costs of capital funding such as interest paid to investors for debts which tend to increase financial expenses resulting to a negative effects on net income and consequently leading to the decrease in operational self-sufficiency. This result is in line with the findings in the study of Hartarska et al. (2007), Hoque et al. (2011), Ngo (2012) and Quayes (2012). Moreover, finding the same results, Kinde (2012) argued that the more the microfinance institutions are financed by debt, the more they will be deficient in their operational self-sufficiency. On the contrary, Dissanayake (2014) and Abrar and Javaid (2014) evidenced a positive relationship between debt to equity ratio and operational self-sufficiency.

Further, the results indicated that debt to asset ratio inversely affected the operational self-sufficiency. As expected, the coefficient is negative but statistically significant at the 0.05 level. Results show that for one unit increase in debt to asset ratio, operational self-sufficiency is anticipated to decrease by 0.6728 units, when the remaining variables in the model are kept constant. This implies that higher leverage (high debt to asset ratio) does not improve financial performance measured by operational self-sufficiency in microfinance institutions. This evidence is in line with the study of Bogan et al. (2007) and Bogan (2012) whose results also indicated an inverse and statistically significant influence of debt relative to asset ratio on operational self-sufficiency measure of financial performance.

The results of the study, further indicated that institutional size significantly affected the operational selfsufficiency. As expected, the coefficient is positive and statistically significant at the 0.05 level. Results show that for one unit increase in microfinance institution size, operational self-sufficiency is anticipated to increase by 0.0499 units, when the remaining variables in the model are kept constant. This implies that mature microfinance institutions have more resources at their disposal, enjoy higher reputation and economies of scale which increase profitability and consequently the operational self-sufficiency. This finding affirms the dictates of life cycle theory which explains transition and development of microfinance institutions. This result confirms findings in the study of Hartarska et al. (2007), Bogan (2012), Dawar (2014) and Tchuigoua (2015). On the contrary, Avortri \& Wereko (2016) evidenced a negative and statistically significant effect of institutional size on operational selfsufficiency in microfinance institutions in Ghana.

Results from the econometric analysis indicated that institutional age inversely affected the operational selfsufficiency. Unexpectedly, the coefficient is negative and statistically significant at 0.05 level. Results show that for one unit increase in microfinance age, operational self-sufficiency is anticipated to decrease by 0.0152 units, when the remaining variables in the model are kept constant. This result suggests that as microfinance institutions grow older, their operational self-sufficiency diminishes. This could possibly be explained by the tendency of older microfinance institutions to give bigger and unaffordable loans which in turn results into poor operational self-sufficiency. This result concurs with the findings in the study of Cull et al. (2007), Bogan et al. (2007), Bogan (2012) and Awaworyi et al. (2014). However, the study is in contrast with the findings in the study of Ndambu (2011) which applied simple OLS regression model, Adhikary et al. (2014) which used large data set and Generalised Method of Moments and Avortri et al. (2016) who found a positive and statistically significant effect of institutional age on operational self-sufficiency in microfinance institutions. 
Table 4:4 Random Effect Regression Model: Effects of Transformation on Operational Self-Sufficiency

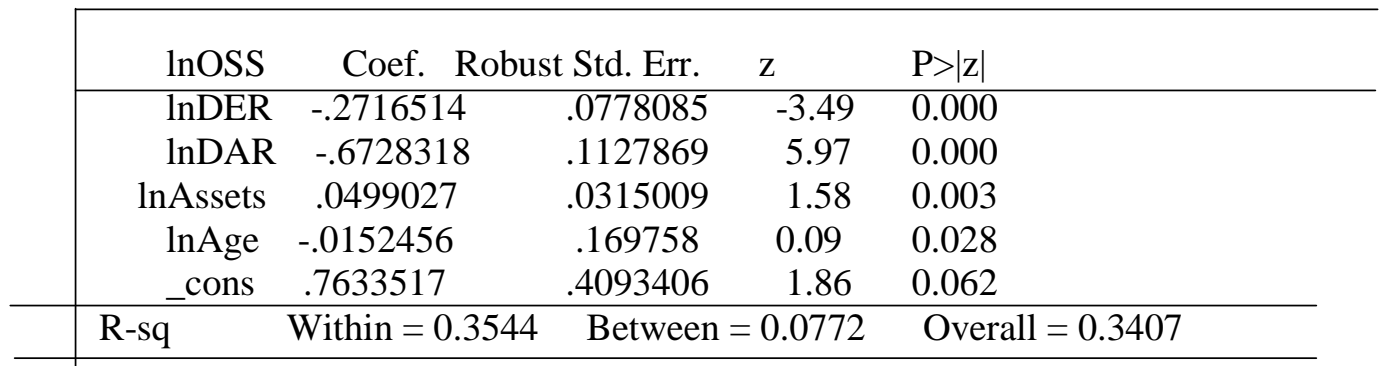

\section{Conclusion and Recommendations}

The study has given an account of the effects of transformation of microfinance NGOs on financial performance. Findings from the empirical analysis have demonstrated a strong influence of debt to equity ratio, debt to asset ratio and institutional size on return on assets, return on equity and operational self-sufficiency measures of financial performance. These current findings lead the study to conclude that access to commercial sources of capital specifically debt to equity ratio and debt to asset ratio significantly influence financial performance while the control variables, that is institutional size and age significantly influence operational self-sustainability of the transformed microfinance NGOs in Kenya.

The study has established the significant dimensions of transformation of microfinance NGOs that should be considered when evaluating the financial performance. Empirical results from the study have confirmed that debt to equity ratio and debt to asset ratio strongly affects financial performance of the transformed microfinance NGOs. Operational self-sustainability is also strongly affected by microfinance institution's size and age. There is, therefore, a definite need for the managers of microfinance NGOs which are faced with pressure for financial performance to establish/adopt policies that will enable microfinance NGOs to transform into regulated financial intermediaries in order to access and utilize commercial sources of capital funding such as debt to enhance financial performance.

\subsection{Limitations and Area for Future Research}

In an attempt to analyse the effects of transformation on financial performance of microfinance NGOs in Kenya, this study used unbalanced panel data of six transformed microfinance NGOs for 19 years. This data might seem too small to enable panel data statistical analysis to find significant relationships in the study variables and come up with more affluent results that can be generalized to a large population. Therefore, as more comprehensive and current data is available, a similar empirical analysis would possibly provide detailed econometric analysis and generate more robust results for generalization to a larger population. Interested studies could also be engaged to investigate the interaction (simultaneous) effects of transformation of microfinance NGOs and measures of financial or outreach on the performance of the transformed microfinance NGOs. The interaction effects study goes beyond investigating the main effects of transformation on financial and outreach performance of microfinance NGOs that this research has established.

\section{References}

Abrar, A., \& Javaid, A. Y. (2014). Commercialization and Mission Drift - A Cross Country Evidence on Transformation of Microfinance Industry. International Journal of Trade, Economics and Finance, 5(1), 122-125.doi.org/10.7763/ijtef.2014.v5.353

Abrar, A., \& Javaid, A. Y. (2016). The Impact of Capital Structure on the Profitability of Microfinance Institutions. South Asian Journal of Management Sciences (SAJMS), Iqra University, 10(1), 2137.doi.org/10.21621/sajms.2016101.03

Adhikary, S., \& Papachristou, G. (2014). Is There a Trade-off between Financial Performance and Outreach in South Asian Microfinance Institutions?. The Journal of Developing Areas, 48(4), 381-402. doi: 10.1353/jda.2014.0081

Adu, J. K., Anarfi, B. O., \& Poku, K. (2014). The Role of Microfinance on Poverty Reduction: A Case Study of Adansi Rural Bank in Ashanti Region of Ghana. Social and Basic Sciences Research Review, 2(3), 96109. 
Akben-Selcuk, E. (2016). Does Firm Age Affect Profitability? Evidence from Turkey. International Journal of Economic Sciences, 5(3), 1-9.doi.org/10.20472/es.2016.5.3.001

Ali, A. E. E. S. (2015). The Regulatory and Supervision Framework of Microfinance in Kenya. International Journal of Social Science Studies, 3(5), 123-130.doi.org/10.11114/ijsss.v3i5.1004

Armendáriz, B and A Vanroose (2009). Uncovering three microfinance myths: Does age Matter? Reflects et Perspectives de la Vie Economique, 48(3), 7-17. doi.org/10.3917/rpve.483.0007

Asian Development Bank. (2000). Finance for the poor: microfinance development strategy. ADB, Manila. Retrieved from: https://www.adb.org/sites/default/files/institutional-document/32094/financepolicy.pdf; [viewed on 22/06/2016]

Avortri, C., \& Wereko, T. B. (2016). The Effect of Services of Micro Financial Institutions on their Financial Performance: A View from Ghana. International Journal of Scientific Research and Innovative Technology, 3(7), 25-42

Awaworyi, S. K., \& Marr, A. (2014). Sustainability and Outreach: A Comparative Study of MFIs in South Asia and Latin America \& the Caribbean. Monash University Department of Economics Working Paper Series, 13, 14. doi.org/10.1111/boer.12100

Bakhtiari, S. (2011). Microfinance and poverty reduction: some international evidence. International Business \& Economics Research Journal (IBER), 5(12).doi.org/10.19030/iber.v5i12.3550

Bakker, A., Schaveling, J., \& Nijhof, A. (2014). Governance and microfinance institutions. Corporate Governance, 14(5), 637-652.doi.org/10.1108/cg-03-2014-0032

Baruah, B. (2010). NGOs in Microfinance: Learning from the Past, Accepting Limitations, and Moving Forward. Geography Compass, 4(8), 979-992. doi:10.1111/j.1749-8198.2010.00362.x

Bass, J., \& Henderson, K. (2000). The Microfinance Experience with Savings Mobilization. USAID Microenterprises Best Practices Project. Weidemann Associates and Development Alternatives, Washington, DC.

Bassem, B. S. (2012). Social and financial performance of microfinance institutions: Is there a trade-off?. Journal of Economics and International Finance, 4(4), 92-100. doi: 10.5897/JEIF11.129

Bayai, I., \& Ikhide, S. (2016a). Financing and Financial Sustainability of Microfinance Institutions (MFIs): A Conceptual View. Banks and Bank Systems (open-access), 11(2). doi:10.21511/bbs.11 (2).2016.03

Bayai, I., \& Ikhide, S. (2016b). Life Cycle Theory and Financial Sustainability of Selected SADC Microfinance Institutions (MFIs). The Journal of Developing Areas, 50(6), 121-132. doi.org/10.1353/jda.2016.0120

Berger, A. N., \& Di Patti, E. B. (2006). Capital structure and firm performance: A new approach to testing agency theory and an application to the banking industry. Journal of Banking \& Finance, 30(4), 10651102.doi.org/10.1016/j.jbankfin.2005.05.015

Berrington, A., Smith, P., \& Sturgis, P. (2006). An overview of methods for the analysis of panel data; Retrieved from http://eprints.ncrm.ac.uk/415/1/MethodsReviewPaperNCRM-007.pdf; [viewed on 22/11/2015]

Bogan, V. L. (2012). Capital structure and sustainability: An empirical study of microfinance institutions. Review of Economics and Statistics, 94(4), 1045-1058.doi.org/10.1162/rest_a_00223

Bogan, V., Johnson, W., \& Mhlanga, N. (2007). Does Capital Structure Affect the Financial Sustainability of Microfinance Institutions. Institute of E-conomies Affair, 7. Retrieved from; http://www.cid.harvard.edu/neudc07/docs/neudc07_poster_bogan.pdf; [viewed on 06/10/2014]

Bowerman, B.L. and O'Connell, R.T. (1990). Linear statistical models: an applied approach. Belmont, CA: Duxbury.

Branch, B., \& Klaehn, J. (2002). The keys to striking the balance: An introduction to savings mobilization. Striking the balance in microfinance: A practical guide to mobilizing savings, 382.

Bruno, O., \& Khachatryan, K. (2011, June). Compulsory versus Voluntary Savings as Incentive Mechanism in Microlending Contracts. In 28e Journées Internationales d'Economie Monétaire.

Campion, A., \& Frankiewicz, C. (1999). Guidelines for the effective governance of microfinance institutions. MicroFinance Network.

Campion, A., \& White, V. (Eds.). (1999). Institutional metamorphosis: Transformation of Microfinance NGOs into Regulated Financial Institutions. MicroFinance Network.

Campion, A., \& White, V. (2001). NGO transformation. Microenterprises Best Practice Project: 31. 
CBK (2015). The Annual Report of the Central Bank of Kenya for the Fiscal Year 2014/15 Report; Retrieved from https://www.centralbank.go.ke/images/docs/CBKAnnualReports/Annual_Report_2015.pdf; [viewed on $21 / 02 / 2016]$

CGAP (2005). Microfinance Consensus Guidelines: Developing Deposit Services for the Poor; CGAP/World Bank:

Chahine, S., \& Tannir, L. (2010). On the Social and Financial Effects of the Transformation of Microfinance NGOs. VOLUNTAS: International Journal of Voluntary and Nonprofit Organizations, 21(3), 440-461. doi:10.1007/s11266-010-9136-6

Charitonenko, S. (2003). Commercialization of Microfinance Philippines. Retrieved from; https://adbtest.atmire.com/bitstream/handle/11540/2380/micro-phi.pdf?sequence=1; [viewed on 06/11/2015]

Chijoriga, M. (2015). Transformation of Non-Governmental Micro Finance Institutions (MFIs) in Tanzania. Business Management Review, 15(1).

Cull, R., Asli Demirgüç-Kunt, A., \& Morduch, J. (2009). Microfinance meets the market. Journal of Economic perspectives, 23(1), 167-92. doi.org/10.1596/1813-9450-4630

D’Espallier, B., Goedecke, J., Hudon, M., \& Mersland, R. (2017). From NGOs to banks: Does institutional transformation alter the business model of microfinance institutions?. World Development, 89, 19-33. doi.org/10.1016/j.worlddev.2016.06.021

Dawar, V. (2014). Agency Theory, Capital Structure and Firm Performance: Some Indian Evidence. Managerial Finance, 40(12), 1190-1206. doi.org/10.1108/mf-10-2013-0275

de Sousa-Shields, M., \& Frankiewicz, C. (2004). Financing Microfinance Institutions: The Context for Transitions to Private Capital. Micro Report, 32.

Dissanayake, D. M. N. S. W. (2014). The Determinants of Microfinance Profitability: Evidences From Sri Lankan Microfinance Institutions. Kelaniya Journal of Management, 1(1), 50. doi.org/10.4038/kjm.v1i1.6446

Dissanayake, D. M. N. S. W. (2012). The determinants of return on equity: evidences from Sri Lankan microfinance institutions. Journal of Arts, Science \& Commerce, 2(2), 26-35

Elser, L., Hannig, A., \& Wisniwski, S. (1999). Comparative Analysis of Savings Mobilization Strategies. Working Group on Savings Mobilization. Eschborn, Alemania: CGAP.

Farrington, T., and Abrams, J. (2002), "The Evolving Capital Structure of Microfinance Institutions", MicroEnterprise Development Review, Washington D.C, Inter-American

Fehr, D.W., and Hishigsuren, G. (2006). Raising capital for microfinance: sources of funding and opportunities for equity financing. Journal of Developmental Entrepreneurship, 11(2), 133-143. doi.org/10.1142/s1084946706000301

Felipe, A. P. (2011, November). MFI Transformations: The LAC Experience. Transforming from NGO to Regulated MFI while Maintaining Your Commitment to Empowering the Poor: A Step by Step Process.". In Global Microcredit Summit Commissioned Workshop Paper.

Fernando, N. A. (2004). Micro success story?: Transformation of Non-Government Organizations into Regulated Financial Institutions; Asian Development Bank. Retrieved from; http://www.adb.org/sites/default/files/publication/27952/micro-success.pdf; [viewed on 16/11/2014]

Frank, C., Lynch, E., \& Schneider-Moretto, L. (2008). Stemming the tide of mission drift: microfinance transformations and the double bottom line. Women's World Banking Focus Note.

FSD-Kenya (2012). Supporting the development of Inclusive Financial Markets in Kenya. FSD-Kenya, Nairobi. Retrieved from; http://www.fsdkenya.org/pdf_documents/13-12-16_FSD_annual_report_2012.pdf; [Viewed on 24/10/2014]

Gallardo, J. (2002). A framework for regulating microfinance institutions: The experience in Ghana and the Philippines. World Bank Policy Research Working Paper, (2755). doi.org/10.1596/1813-9450-2755

Gardiol, I. D. (2004). Mobilizing Savings: Key Issues and Good Practices in Savings Promotion. Swiss Agency for Development and Cooperation.

Grobler, A. (2007), "A Dynamic View on Strategic Resources and Capabilities Applied to an Example from the Manufacturing Strategy Literature", Journal of Manufacturing Technology Management, 18(3), 250-266. doi.org/10.1108/17410380710730594

Hartarska, V. (2005). Governance and performance of microfinance institutions in Central and Eastern Europe and the newly independent states. World development, 33(10), 1627-1643.

doi.org/10.1016/j.worlddev.2005.06.001 
Hartarska, V., \& Nadolnyak, D. (2007). Do regulated microfinance institutions achieve better sustainability and outreach? Cross-country evidence. Applied economics, 39(10), 1207-1222. doi: 10.1080/00036840500461840

Hayes, A. F., \& Cai, L. (2007). Using Heteroskedasticity-Consistent Standard Error Estimators in OLS regression: An Introduction and Software Implementation. Behavior Research Methods, 39(4), 709-722. doi.org/10.3758/bf03192961

Helms, B. (2006). Access for all: building inclusive financial systems. Washington, DC, C-GAP.

Hermes, N., Lensink, R., \& Meesters, A. (2011). Outreach and efficiency of microfinance institutions. World Development, 39(6), 938-948.doi.org/10.1016/j.worlddev.2009.10.018

Hishigsuren, G. (2007). Evaluating Mission Drift in Microfinance Lessons for Programs With Social Mission. Evaluation Review, 31(3), 203-260. doi: 10.1177/0193841X06297886

Hoque, M., Chishty, M., \& Halloway, R. (2011). Commercialization and Changes in Capital Structure in Microfinance Institutions: An Innovation or Wrong Turn?. Managerial Finance, 37(5), 414-425. doi: 10.1108/03074351111126906

Hubka, A., \& Zaidi, R. (2005). Impact of government regulation on microfinance. Retrieved from; http://siteresources.worldbank.org/INTWDRS/Resources/477365-

1327693758977/Hubka_Zaidi_Impact_of_Government_Regulation. pdf ; [Viewed on 07/11/2014]

Javed, Z. H., Rao, H. H., Akram, B., \& Nazir, M. F. (2015). Effect of Financial Leverage on Performance of the Firms: Empirical Evidence from Pakistan. SPOUDAI-Journal of Economics and Business, 65(1-2), 87-95.

Johnson, P., \& Duberley, J. (2000). Understanding management research: An introduction to epistemology. Sage.

Kar, A. K. (2013). Double bottom lines in microfinance: are they mutually exclusive?. Journal of Small Business \& Entrepreneurship, 26(1), 87-107. doi: 10.1080/08276331.2012.761804

Kar, A. K. (2011). Microfinance institutions: A cross-country empirical investigation of outreach and sustainability. Journal of Small Business \& Entrepreneurship, 24(3), 427-446. doi.org/10.1080/08276331.2011.10593547

Katz, M. H. (2011). Multivariable analysis: A practical guide for clinical and public health researchers (3rd ed.). New York, NY: Cambridge University Press.

Khan, A. A. (2008). Paradigm Shift in the Microfinance Sector and its Implications for Theory Development: Empirical Evidence from Pakistan. Australasian Accounting, Business and Finance Journal, 2(4), 6-32.

Khan, M. M. (2015). Credit Constraints for Microfinance Sector in Pakistan, an Analysis of Internal and External Factors. International Letters of Social and Humanistic Sciences, 47, 164-173. doi.org/10.18052/www.scipress.com/ilshs.47.164

Kinde, B. A. (2012). Financial Sustainability of Microfinance Institutions (MFIs) in Ethiopia. European Journal of Business and Management, 4(15), 1-10.

King'ori, S., Kioko, W., \& Shikumo, H. (2017). Determinants of Financial Performance of Microfinance Banks in Kenya. Research Journal of Finance and Accounting, 8(16), 1-8

Kipesha, E. F. (2013). Performance of Microfinance Institutions in Tanzania: integrating financial and nonfinancial metrics. European Journal of Business and Management, 5(4), 94-105.

Kipesha, E. F., \& Zhang, X. (2013). Sustainability, Profitability and Outreach Tradeoffs: Evidences from Microfinance Institutions in East Africa. European Journal of Business and Management, 5(8), 136-148.

Kodongo, O., Mokoaleli-Mokoteli, T., \& Maina, L. N. (2015). Capital structure, profitability and firm value: panel evidence of listed firms in Kenya. African Finance Journal, 17(1), 1-20. doi.org/10.2139/ssrn.2465422

Kyereboah-Coleman, A. (2007). The impact of capital structure on the performance of microfinance institutions. The Journal of Risk Finance, 8(1), 56-71.doi.org/10.1108/15265940710721082

Kyereboah-Coleman, A., \& Osei, K. A. (2008). Outreach and profitability of microfinance institutions: the role of governance. Journal of Economic Studies, 35(3), 236-248.DOI 10.1108/01443580810887797

Ledgerwood, J. (1999), Microfinance Handbook, An Institutional and Financial Perspective, Washington DC; The World Bank

Ledgerwood, J., \& White, V. (2006). Transforming Microfinance Institutions: Providing Full Financial Services to the Poor. World Bank Publications; doi: 10.1596/978-0-8213-6615-8.

Long, J. S., \& Ervin, L. H. (2000). Using heteroscedasticity consistent standard errors in the linear regression model. The American Statistician, 54(3), 217-224. doi.org/10.2307/2685594 
Louis, P., \& Baesens, B. (2013). Do for-profit microfinance institutions achieve better financial efficiency and social impact? A generalised estimating equations panel data approach. Journal of Development Effectiveness, 5(3), 359-380.doi:10.1080/19439342.2013.822015

Maes, J. P., \& Reed, L. R. (2012). State of the Microcredit Summit Campaign Report 2012. Microcredit Summit Campaign. Retrieved from; http://www.microcreditsummit.org/uploads/resource/document/web_socr2012_english_62819.pdf; [viewed on 10/11/2014]

Maina, L., \& Ishmail, M. (2014). Capital structure and financial performance in Kenya: Evidence from firms listed at the Nairobi Securities Exchange. International Journal of Social Sciences and Entrepreneurship, 1(11), 209-223.

Maisch, F. P., Soria, A. T., \& Westley, G. D. (2006). How should microfinance institutions best fund themselves?. Inter-American Development Bank Sustainable Development Departament Best Practices Series.

Marr, A., \& Tubaro, P. (2013). The microfinance wholesale lending market: a comparative study of India, Peru and Tanzania. International Journal of Economics and Business Research,5(1), 33-54.doi: 10.1504/IJEBR.2013.050641

McGuire, P. B., \& Conroy, J. D. (2000). The microfinance phenomenon. Asia Pacific Review, 7(1), 90-108. doi.org/10.1080/713650817

Mersland, R., \& Strøm, R. Ø. (2007). Microbanks: Ownership, performance and social tradeoffs-a global analysis.

Morduch, J. (2000). The microfinance schism. World development, 28(4), 617-629. doi.org/10.1016/s0305750x(99)00151-5

Mori, N., \& Olomi, D. R. (2012). The effect of boards on the performance of microfinance institutions: evidence from Tanzania and Kenya. Research on Poverty Alleviation (REPOA).

Mukherjee, J., \& Wisniwski, S. (1998). Savings mobilization strategies: lessons from four experiences.

Mustafa, A. K. A., \& Saat, M. M. (2013). Microfinance Institutions Performance Measurement: Introducing a New Performance Measurement Framework. Middle-East Journal of Scientific Research, 15(11), 16181628. doi: 10.5829/idosi.mejsr.2013.15.11.11644

Mwizarubi, M., Singh, H., Mnzava, B., \& Prusty, S. (2016). Emerging Paradigms of Financing Tanzanian Microfinance Institutions and their Impact on Financial Sustainability-Part I. World, 6(1).

Myers, R. (1990). Classical and modern regression with applications. Boston: Duxbury.

Ndambu, J. (2011). Does regulation increase microfinance performance in Sub-Saharan Africa. Technical Note, (3).

Ngo, T. V. (2012). Capital structure and microfinance performance: a cross-country analysis and case study of Vietnam (Doctoral dissertation, University of Birmingham).

O'brien, R. M. (2007). A Caution Regarding Rules of Thumb for Variance Inflation Factors. Quality \& Quantity, 41(5), 673-690. doi.org/10.1007/s11135-006-9018-6

Okumu, L. J. (2007). The microfinance industry in Uganda: sustainability, outreach and regulation (Doctoral dissertation, Stellenbosch: University of Stellenbosch).

Olivares-Polanco, F. (2005). Commercializing microfinance and deepening outreach? Empirical evidence from Latin America. ESR Review, 7(2), 47.

Olivier, B. (2011). Compulsory versus Voluntary Savings as Incentive Mechanism in Microlending Contracts. Business research and development, 2(2), 35-42.

Omare, O. S. (2017). Effect of Capital Structure on Performance of Microfinance Institutions: A Case of Deposit Taking Microfinance Institutions in Kenya. International Journal of Business Management and Finance, 1(7), 105-120.

Park, H. M. (2015). Linear regression models for panel data using SAS, Stata, LIMDEP, and SPSS.

Prakash, S. (2016). Return on Assets as a Measure of Financial Sustainability of Microfinance Institutions in India. Asian-African Journal of Economics and Econometrics, 16(1), 119-128

Pytkowska, J. (2006). Is Commercial Financing a Growth Engine for Microfinance Institutions?. Finance \& Bien Commun, (2), 101-104.doi.org/10.3917/fbc.025.0101

Quayes, S. (2012). Depth of Outreach and Financial Sustainability of Microfinance Institutions. Applied Economics, 44(26), 3421-3433;doi:10.1080/00036846.2011.577016

Quayes, S. (2015). Outreach and performance of microfinance institutions: a panel analysis. Applied Economics, 47(18), 1909-1925. doi.org/10.1080/00036846.2014.1002891 
Quayes, S., \& Hasan, T. (2014). Financial disclosure and performance of microfinance institutions. Journal of Accounting and Organizational Change, 10(3), 314-337. doi 10.1108/JAOC-12-2011-0067

Rahman, M. A., \& Mazlan, A. R. (2014). Determinants of Financial Sustainability of Microfinance Institutions in Bangladesh. International Journal of Economics and Finance, 6(9), 107-116. doi.org/10.5539/ijef.v6n9p107

Rao, M. K., Kumar L. M., Pathrudu M. S. (2015). Financial Performance of Selected Micro Finance Institutions In Andhra Pradesh-A Study. Journal of Business and Management, 18(10), $50-55$.

Robinson, M. (2004). Mobilizing savings from the public: Basic principles and practices. Kampala, Uganda: SPEED-USAID, March.

Ronoh, C., \& Ntoiti, J. (2015). Effect of capital structure on financial performance of listed commercial banks in Kenya. A case study of Kenya commercial bank limited. The Strategic Journal of Business and Change Management, 2(72), 750-781

Sarma, S. (2011). NGO transformation: institutional entrepreneurship in Indian microfinance. Business Strategy Series, 12(4), 167-176. doi.10.1108/17515631111155124

Schäfer, K., \& Fukasawa, Y. (2011). Factors Determining the Operational self-sufficiency among Microfinance Institutions. Advances in Business Research, 2(1), 172-178

Sekabira, H. (2013). Capital structure and its role on performance of microfinance institutions: The Ugandan case. Sustainable Agriculture Research, 2(3), 86. doi:10.5539/sar.v2n3p86

Shah, M. (2011). Regulating Pakistan's Non-Bank Microfinance Institutions. MicroNote: Pakistan Microfinance Network, 14(1), 1-16.

Shu, C. A., \& Oney, B. (2014). Outreach and performance analysis of microfinance institutions in Cameroon. Ekonomska istraživanja, 27(1), 107-119. doi.org/10.1080/1331677x.2014.947108

Singh, S., Goyal, S. K., \& Sharma, S. K. (2013). Technical efficiency and its determinants in microfinance institutions in India: a firm level analysis. Journal of Innovation Economics \& Management, (1), 15-31. doi.org/10.3917/jie.011.0015

Tabachnick, B. G., \& Fidell, L. S. (2001). Using Multivariate Statistics. Boston, MA: Pearson, Education, Inc.

Tchuigoua, H. T. (2014). Institutional framework and capital structure of microfinance institutions. Journal of Business Research, 67(10), 2185-2197. doi.org/10.1016/j.jbusres.2014.01.008

Tchuigoua, H. T. (2015). Capital structure of microfinance institutions. Journal of Financial Services Research, 47(3), 313-340. doi.org/10.1007/s10693-013-0190-2

Teece,D. J., Pisano, G., \& Shuen, A.(1997). Dynamic capabilities and strategic management. Strategic management journal,509-533.doi.org/10.1002/(sici)1097-0266(199708)18:7<509::aid-smj882>3.0.co;2-z

Tuyishime, R., Memba, F., \& Mbera, Z. (2015). The Effects of Deposits Mobilization on Financial Performance in Commercial Banks in Rwanda. A Case of Equity Bank Rwanda Limited. International Journal of Small Business and Entrepreneurship Research, 3(6), 44-71.

Van de Ven, A. H., \& Poole, M. S. (1995). Explaining development and change in organizations. Academy of management review, 20(3), 510-540.

Wagenaar, K. (2012). Institutional transformation and mission drift in microfinance. Centre of Development Studies, University of Cambridge.

Woller, G. M., Dunford, C., \& Woodworth, W. (1999). Where to microfinance. International Journal of Economic Development, 1(1), 29-64.

Zaidi, M. F. A., \& Othman, S. N. (2012). Understanding the Concept of Dynamic Capabilities by Dismantling Teece, Pisano, and Shuen (1997)'s Definition. International Journal of Academic Research in Business and Social Sciences, 2(8), 367. 